\title{
The relation between creation and salvation in the Trinitarian theology of Robert Jenson
}

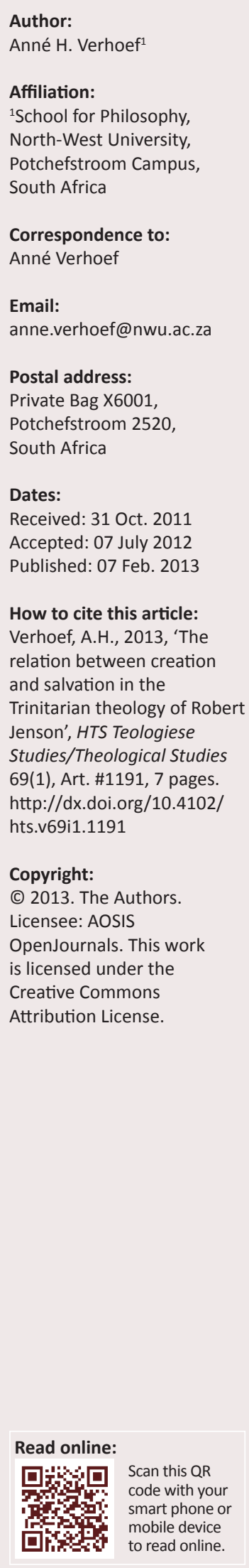

This article explored the relation between creation and salvation as acts of God in the theology of Robert Jenson, an American Lutheran theologian. This is important due to Jenson's growing importance as theologian and because of the current importance of ecotheology (and related themes that were implicated by the relation between creation and salvation). Jenson's theology is an effort to tell God's particular story and it can be described as a Trinitarian, narrative and eschatological theology. His starting point is that God's eternity must not be understood as timeless (this is unbiblical and incompatible with the story of creation and redemption) and that creation (space and time) takes place somehow within the being of God. Jenson qualified this 'withinness', but also emphasised that creation is an intelligible whole, a history with an intended end. It is important for him that God's story - a story of dramatic coherence - is not separated from our own and creation's story. Within this understanding of God's story (as dramatic coherence), creation found its own dramatic teleology because salvation also includes creation. Creation is therefore not subjected to pointlessness any longer, but will find its final place within God. The implication of this is that we must value creation much more and act with more responsibility towards it. According to Jenson we must enjoy creation in an aesthetic fashion and delight in creation as a whole because of its dramatic teleology.

\section{Introduction}

To investigate the relation between creation and salvation as acts of God in the theology of Robert Jenson is a complex and challenging task. Jenson's theology is written as a coherent system in which all loci are closely interwoven. To comprehend this system is already difficult and it is even more difficult to account for the relationship between two such important themes. Jenson does however give ample attention to these themes in his theology and because of Jenson's growing importance as theologian on the one hand, and the current importance of ecotheology (and related themes) on the other, it is worth the effort to reconstruct his position on these themes and to identify their implications.

\section{Jenson as an American Lutheran theologian}

Robert W. Jenson was born on 02 August 1930 in Eau Claire, Wisconsin, in the United States of America. He studied and worked in Germany, the United Kingdom and in the United States and before his retirement in 2005, from 1998 he was a senior scholar for research at the Center of Theological Inquiry in Princeton, New Jersey. He taught at Luther College in Decorah, Iowa (1961-1966), at the Lutheran Theological Seminary in Gettysburg, PA (1968-1988) and also at St Olaf College in Northfield, MN (1988-1998). He was also the ‘Lutheran World Federation lecturer in Theology' at Oxford in the United Kingdom (1966-1968; 1972-1973).

Jenson did his doctoral studies under Peter Brunner in Heidelberg on the theology of Karl Barth. His first book in 1963 was a revised edition of his doctoral thesis with the title Alpha and Omega, A Study in the Theology of Karl Barth. This was the first of many books and articles on Barth's theology and the influence of Barth on his theology is apparent. However, whilst Barth was classically Augustinian (in respect to the doctrine of God's eternity) Jenson is one of several seminal theologians of our time who have pointed to the importance of the Cappadocian Fathers as sources for the reappropriation of Trinitarian insights that the West has for the most part neglected (Gunton 2000a:82). This is apparent from Jenson's book The Triune Identity: God according to the Gospel (1982). Herein the specific influence of Gregory of Nyssa on Jenson's thoughts is evident.

Jenson's theology can be described by terms such as Trinitarian, narrative, eschatological, ecumenical and ecclesiological. All these themes he addressed in the many books he has written. Some of his main dogmatic works include: Systematic Theology, Volume 1: The Triune God (1997) and Systematic Theology, Volume 2: The Works of God (1999); God after God: The God of the Past and the God of the Future, Seen in the Work of Karl Barth (1969); Alpha and Omega (1963, 1969); Triune Identity (1982); Christian Dogmatics (1984 with Carl Braaten); and Story and Promise: A Brief Theology 
of the Gospel about Jesus (1973). Of these books, his Systematic Theology should be singled out as his magnum opus in which he systematically synthesised his creative Trinitarian theology that had developed over many years.

Jenson's more ecumenically focused books were mostly written later in his life and include: Visible Words: The Interpretation and Practice of the Christian Sacraments (1978); Unbaptized God: The Basic flaw in Ecumenical Theology (1992); The Catholicity of the Reformation (1996); Jews and Christians (2003); In One Body through the Cross: The Princeton Proposal for Christian Unity (2003) and The Ecumenical Future (2004). The last four books were written or co-edited with his lifelong friend and colleague, Carl Braaten. These ecumenical works emphasise the fact that although Jenson is a Lutheran theologian he will not have his systematic theology labelled as 'Lutheran theology'. He works out his theology in the context and in 'anticipation of the one church' and he says himself that 'some of its key positions are reinventions of Orthodox wheels', while on the other hand he 'espouses [to] the Catholic side' (Jenson 1997:viii).

It is not only Jenson's books that testify about him as an important and significant Trinitarian theologian, but also the reaction on his books and other works (Verhoef 2011b:247). He is widely regarded as one of the foremost Trinitarian theologians of the last half of the 20th century. Wolfhart Pannenberg (2000) writes for example:

Since the 1960s, his [Jenson] books on the concept of God, on eschatological theology, on the Trinity, and on ecumenism have established him as one of the most original and knowledgeable theologians of our time. (p. 49)

Many other respected theologians from different denominations and from all over the world share this high esteem for Jenson's theology. Some regard him as one of the most significant American theologians of our day and even his most stringent critics have a lot of admiration for his Trinitarian theology. This is (amongst others) evident in the book Trinity, Time, and Church: A Response to the Theology of Robert W. Jenson (edited by Gunton 2000b), in which theologians from all over the world and from many different denominations contributed essays of appreciation and dialogue with Jenson's theology. The title of this book, Trinity, Time, and Church, gives an indication of the main themes of Jenson's theology. These themes are highly relevant for practising theologians today and this article, with its focus on the relation between creation and salvation within the Trinitarian theology of Jenson, is an example thereof.

\section{Theology as story and promise}

In his book Story and Promise (1973), in his article 'How the world lost its story' (1993), and throughout his Systematic Theology $(1997,1999)$, the two themes of story and promise are very pertinent in Jenson's theology. In reaction to postmodernism's loss of story and promise Jenson developed his theology as a story of hope. It is important for Jenson to tell God's story as it is revealed through the name Father, Son and Holy Spirit, because God's name is for him a maximally compressed version of the one God's particular story.
Jenson's theology is an effort to tell this particular story and therefore it can be described as a Trinitarian, narrative and eschatological theology (Verhoef 2008:235).

The way in which Jenson tells this story of God begins with his notion that the immanent Trinity is the economic Trinity. This viewpoint is not so unique to Jenson's theology, but in Jenson's presentation the difference between the 'immanent' Trinity and the 'economic' Trinity, almost vanishes so that there is no 'analogical interval' between the two (Hart 2005:31). There is no difference between the God of eternity (in his eternal life) and the God who became man in Jesus Christ in specific time (the Trinitarian God in the history of salvation). This view of Jenson leads to a very specific understanding about the relationship between God and time in which Jenson regards the definition of God's eternity as timeless as unbiblical and incompatible with the story of creation and redemption. God is not timeless, but God is 'identified by specific temporal actions and is known within certain temporal communities by personal names and identifying descriptions thereby provided' (Jenson 1997:44). God is not timeless, but lively, active, an event. The God of the Bible is thus identified by temporal events, and indeed by a history of such events. Jenson boldly integrates this insight with his Trinitarian theology by conceiving of the biblical narrative as the final truth of God's own reality in the mutual relations of God the Father, His incarnate Son, and the eschatological accomplishment of their communion with the Spirit (Pannenberg 2000:49). God's story takes on an ontological status and God is not God without his story.

This has the implication that time is not something immune to God, but something within the Trinity (as will be explained later). In his narrative theology Jenson tries to avoid timelessness of God on the one hand and tries to maintain God's perichoresis on the other hand (Verhoef 2011b:251). The 'timefulness' of God (Jenson uses the term 'temporal infinity') is thus central to the relations within the Trinity and for Jenson there is a clear connection between the poles of time and the mutual triune roles of Father, Son, and Spirit. According to him the "Father is the "whence" of God's life; the Spirit is the "whither" of God's life; and ... the Son is that life's specious present' (Jenson 1997:218-219). Creation, redemption and fulfilment are thus all included within the Trinitarian life or story of God. From the accounts of creation onwards, the grand narrative is not a mythic account, with purely ontological, a-temporal claims, but rather a purposive entity with a history. It is thus within the triune God that the world (the cosmos and us) finds its story (and meaning) and promise (and hope).

\section{Creation}

Jenson (1999) takes his model of creation from John of Damascus and emphasises God's 'timefulness' by saying that creation is done:

between all temporal dimensions by the three persons God is: God the Father is the sheer given of creation; God the Spirit is the perfecting Freedom that animates creation; God the Son is the mediator of creation. (p. 25) 
It is within the Trinitarian relations where creation takes place and Jenson (1997) says God as:

Father, Son and Spirit can make room in himself for others, and the room he makes is our created time. The opening of that room is the act of creation. (p. 226)

In his doctrine of creation Jenson continues thus his assault on the divine timelessness of religion that posits a deistic God and leaves us with questions about God's immanence. In contrast Jenson states that creation takes place in some way within the being of God. He uses a metaphor and says God 'opens room' or 'makes accommodation' in himself to create and therefore Jenson speaks of God's 'roominess'. His central proposal is that:

For God to create is for him to make accommodation in his triune life for other persons and things than the three whose mutual life he is. In himself, he opens room, and that act is the event of creation. (Jenson 1999:25)

He calls this accommodation in the triune life 'time' and says that 'created time is accommodation in God's eternity for others than God' (Jenson 1999:25).

This opening of room (space and time as creation) within God is possible because of his Trinitarian relations:

The Spirit is Spiritus Creator as he frees the Father from retaining all being with himself and so frees what the Father initiates from being the mere emanation it would have been were the Father God by himself. (Jenson 1999:26)

The work of the Son in this is that 'he mediates between the Father's originating and the Spirit's liberating' (Jenson 1999:26-27), 'thereby to hold open the creatures' space in being' (Jenson 1999:27). In this way Jenson makes a notion of creation not only as taking place within God, but also as 'externalisation'. However, he does not move away from the notion of creation as the opening up of space for creatures within the divine being, but rather takes care to qualify this 'withinness'. He says that:

God makes narrative room in his triune life for others than himself; this act is the act of creation ... Thus as we 'live and move and have our being' in him, the 'distention' within which we do this is an order external to us ... (Jenson 1999:34)

And to 'be a creature in specific relation to the Father is to be a motif in the orchestration that occurs when God's musicality opens ad extra' (Jenson 1999:39). The 'ad extra' is significant in terms of Jenson's insistence on creation that is in some sense within God's being. He balances this internality and otherness by saying:

Insofar as to be a creature is to be other than God, we may say that the Father's love of the Son as other than himself is the possibility of creation's otherness from God ... Moreover, we now also see why we had to say that time was the 'room' God made for us in his life: did not God set us other than himself, did he not make space between him and us, all time would just be his time and there would be no 'accommodation' in him. (Jenson 1999:48)

How can what is within God, fail to be part of God? And can this 'withinness' of creation, as Jenson describes it, be pushed in a panentheistic direction? Firstly, it is important to remember that we are here in the realm of a metaphor in terms of which the continuing relatedness of the creation to God is being constructed by Jenson. Secondly, Jenson says that God 'must have his own place within creation if he is not simply to absorb the creature within himself' (Jenson 1999:120) and according to him this 'own place' of God is heaven. Heaven as God's own space is:

The space between the man Jesus and the Father, insofar as this space is at once the space between a creature and God and the inner-triune difference between the Son and the Father. The latter difference is the possibility of space and creatures in it; its identity with the former is the possibility of God's spatial location over against them. (Jenson 1999:123)

Jenson remains thus well short of committing to panentheism although he has been accused of 'pan-en-trinitarianism' (Mattes 2000:484). This accusation is a consequence of Jenson's specific understanding of the immanent Trinity as the economic Trinity (or vice versa). David Hart criticised him on this point for not allowing for an 'analogical interval' between the two (Hart 2005:31), but perhaps Pannenberg's critique indicates the implications of this position (of Jenson) for the relation between God and creation the best - which might also implicate Jenson as a 'process theologian' (Verhoef 2011a:105-109). Pannenberg (2000) says:

It is certainly true that the trinitarian God in the history of salvation is the same God as in His eternal life. But there is also a necessary distinction that maintains the priority of the eternal communion's explication in the history of salvation. Without that distinction, the reality of the one God tends to be dissolved into the process of the world. (p. 50)

Creation, as space and time 'within God's being', is however in coherence with Jenson's whole narrative and Trinitarian theology. He can thus say 'God makes narrative room in his triune life for others than himself; this act is the act of creation' (Jenson 1999:34) and 'God does not create spatial objects that thereupon move through time; he creates temporalspatial objects, that is, in a more precise language, he creates histories' (Jenson 1999:46). The story of God, which includes the story of creation, is that God does not create a cosmos which thereupon is shocked into movement so as to have a history, but that God creates precisely a history. The universe is for Jenson an intelligible whole, a history, because it has an intended end. Jenson says 'the End, human and cosmic, will be the great triumph of the Spirit, that is, of freedom and love' (Jenson 1999:351). Creation is thus a story with a promise. It is part of God's story and his promise.

\section{Sin and salvation}

Jenson defines sin as that what God does not want done. He sees sin primarily as idolatry or unbelief, but also as lust, injustice and despair (Jenson 1999:133-150). He follows Aquina's exposition and says sin is 'original' in that none of us has an origin prior to it and in that humanity as a whole somehow sins as one: 'Humanity is finally one diachronically extended community and we in it are idolatrous, lustful, unjust, and despairing' (Jenson 1999:150). For Jenson we are therefore compelled to posit a 'fall' of humankind occurring 
within created time and therefore the story told in the third chapter of Genesis is taken by Jenson as a description of the historical first happening of what thereafter always happens. Adam and Eve constitute the first community of our biological ancestors who disobeyed God's command.

Jenson rejects the view that reconciliation is only God's reaction to human sin and says it must be part of God's eternal will to rescue us in Christ. So, the coming of Jesus to sinful man is not to be understood as a mere stratagem on God's part. It is however part of the real historical encounter between the forces of good and evil - the fall and redemption that happen in created time (Forde 2000:127-131). Jenson is careful not to understand the whole history as something with a solution given in advance because creation and reconciliation will then collapse into each other. The problem for Jenson will then be that if reconciliation is already comprehended in creation, then nothing essential happens in our time. This would not fit into his description of God's story as one of dramatic coherence. For Jenson, the unity of creation and reconciliation lies in Jesus Christ, in this 'one person in his history, and thus it cannot be determined in advance' (Forde 2000:128). It occurs in Jesus' life history - it is in it (and not before or after it) that the story of God finds its dramatic coherence. In other words: in Jesus' life history we find the unity of creation and salvation and not somewhere else.

God's love for sinners in Christ is thus not merely God's 'accommodation to an unfortunate situation, but as the opening of a depth in God in which he loves and sacrifices himself for the sinner as sinner' (Forde 2000:129). The cross exposes us as rebels seeking to eliminate God from our lives, despite the fact that we, and our world, are God's good creation. In the cross God saves in that he condemns and rejects our rebellion, and thereby claims us as his own. Our salvation lies thus in a decision of God and grace is not a repair job. Grace is rather 'God's will and the basis of our whole existence' (Forde 2000:129). On the one hand it is God's eternal will to create us as creatures destined to participate in his life - God is eternally determined to reconcile sinful creatures with himself by sending his Son and directing history to that goal. On the other hand God's will and the direction of history are hidden by human rebellion and God's judgement. Jenson says the Gospel does not explain the rule of history's hidden Lord and that one does not see through history in advance by means of a series of 'in order that's.' The unity of God's one eternal will is for Jenson an event that occurred in time at the cross. Jenson's polemic against timelessness is thus constant throughout his argumentation and therefore he says for example that Jesus Christ should be seen as God's great decision about us in our history, and 'not as an event in a "third" level between time and eternity. In our history God makes His eternal decision' (Jenson 1963:163).

What implication has this for creation? According to Jenson, the Pauline passage of Romans 8:20-23 indicates an analogy to human sin in the rest of creation. Creation, as human and other than human, is in this text the subject of suffering and striving. Jenson says creation as a whole has not itself willed its condition and awaits its great deliverance, but creation is until then subjected to pointlessness and to endings that are merely endings: 'The world that tempts us to take it as a pointless and declining cosmos is a world whose true teleology has somehow been agonizingly suspended' (Jenson 1999:151). This subjection of creation is, according to Paul (in Jenson's interpretation), decreed by God as a hopeful act. Although Paul does not explicitly state how this act can be hopeful, Jenson (1999) says that the:

$[P]$ resumption must be that a creation that simply continued on the way of its own teleology while humanity went on the way of sin could not suffer the birth pangs of that humanity's redemption, while an adoption of human children into glory that occurred independently of the rest of creation would not be a 'redemption of the body'. (p. 151)

The creation must thus be included in salvation and the implication is that it is somehow affected by human sin - our world longs for redemption from the curse of humanity's sin, its subjection to pointlessness.

There is however the mystery of evil that is not sin or caused by $\sin$, of 'arbitrary disaster to the garden we are given to tend and of undeserved ... disaster to us from that garden' (Jenson 1999:151). This is all part of the actual creation God has made with the teleology with which he made it. Therefore Jenson (1999) says, in following Paul's presumptions, that:

[If] the whole creation has a goal, and if that goal is the adoption into God of the totus Christus, of Jesus with his sisters and brothers, then sin and Crucifixion must be the crises of all creation's teleology, as this is actually worked out within God's will. It is vital to remember that the creation's teleology is a dramatic teleology, so that such crises cannot be strange to it. (p. 151)

The goal of creation is thus affected by sin and that is why Paul (and Jenson) says the cosmos itself has a curse of pointlessness in which all events seem to lead into empty infinity. The sin of humans, of denying our goal in God, is also true of creation (it denies its goal in God), so that it loses its meaning. Therefore Jenson says the 'very course of cosmic events, insofar as it evidently tends toward either pointless infinite continuance or toward collapse back into nothingness, is other than it might have been' (Jenson 1999:152).

The 'dramatic teleology of creation' that Jenson refers to, fits in on the one hand with his soteriology as being rooted in the divine eternal will of God - salvation is not the result of an alteration in the divine will due to human sin, but is God's carrying to perfection his eternal will in Jesus Christ. On the other hand, it is also something that must be described as an event in our history. The actual event of the cross and resurrection - its historical nature - is thus for Jenson very important, especially in his understanding of God's story as dramatic coherence.

Jenson recasts therefore the doctrine of predestination to one of 'postdestination'. Jenson first reclaims Barth's Christological move that election is done through the proclamation of Jesus Christ (and not abstractly by a God in eternity separating souls ... apart from Trinitarian relations) and then he makes the 'Spirit discourse' rather than Father 
or Son discourse the primary location of his interpretation: 'The eternity of the moment of the divine choosing must be established by changing the prefix in predestination to "post-" rather than "pre-" (Forde 2000:134). To speak then of the 'postdestination' of the Spirit, opens up a way for Jenson to explain the reconciliation between God's absolute love and God's mere absoluteness. On the one hand, God's will is absolute because it is immutable love, but on the other hand 'whatever happens, God wills it. Yet that means that for the time being God is hidden and faith is a "desperate conflict within encompassing hope"' (Forde 2000:134). 'Postdestination' is thus, for Jenson, a better option to construct theodicies of God's immutable love on the one hand and the existence of evil and disasters of creation and human perfidy on the other.

It is clear that Jenson's 'dramatic teleology of creation' is tightly interwoven with his understanding of justification as an event, with his view of soteriology as being eternal and in created time, with his emphasis on the Trinitarian relations, and his understanding of God's story as dramatic coherence. All these themes come together when Jenson gives specific prominence to the resurrection. The resurrection must be taken together with the crucifixion 'as the necessary conclusion and bearer of the meaning, so to speak, of the narrative' (Forde 2000:135). The crucifixion is good only when it is dramatically linked with the resurrection (Jenson 1997:190). The unity of the crucifixion and the resurrection is thus a narrative unity. It is for Jenson a dramatic unity - a unity of the narrative itself - and therefore the narrative itself must carry the weight. Jenson (1997) says:

The Gospel tells a powerful and biblically integrated story of the Crucifixion; this story is just so the story of God's act to bring us back to himself at his own cost, and of our being brought back. ... that is the real story of what God does to reconcile us ... The Gospel's passion narrative is the authentic and entire account of God's reconciling action and our reconciliation, as events in his life and ours. (p. 189)

\section{Salvation as reconciliation}

Jenson's doctrine of justification (Jenson 1999:290-301) is situated primarily within the doctrine of the Trinity and is described by Jenson (1999) as a triune event:

What then is justification? It is the underived event of communal faithfulness in God, as this is set free by the Spirit and is actual in the reality of the incarnate Son. That we are justified means that this history is not only God's but is made to be ours also. (p. 301)

Jenson explains this whole doctrine in terms of a Trinitarian ontology (Jenson 1995:425-426; Mannermaa 2000:145) and states that:

... we come before God the Father to receive God the Spirit just and only as we are one with God the Son. Thus we are first within God, and only thereby opened to him so that he can also, by the infinite perichoresis of his life and our participation in it, be within us (Jenson 1995:426).

Justification as an act of the Spirit is the fulfilling of righteousness. The sending of the Spirit is the movement of our righteousness, its eschatological liveliness. The Spirit is 'the movement of God's own righteousness, insofar as this too is not a timeless fact about God but rather the liveliness of his life' (Jenson 1995:426).

So to be justified means, according to Jenson that we, as the body and spouse of the Son, are included in the event of communal faithfulness in God. We are reconciled to God to become part of his perichoresis, his community. Salvation is thus entry into the life of the triune God (as part of the inexhaustibility of the particular advent of Christ), but Jenson adds that fulfilment would be entry into 'God's specific infinity' (Jenson 1999:318). This will take place with the final judgement as the 'rectification of the community of God's people by bringing them into exact concert with the triune community and its righteousness, as this is defined by Christ's death and Resurrection' (Jenson 1999:326). The Last Judgement is thus for Jenson in all its ways a closure of the human narrative, but also for creation. He says:

[C]losure is demanded by the very character of God's creation: he creates not a cosmos that goes on forever or perhaps just stops but a history that is creation because its closure makes it a whole (Jenson 1999:336).

The story of God, his creation and us, have thus a very specific promise. This promise is one of deification and Jenson discusses it as the 'great transformation' that will take place.

\section{Promise of deification}

The specific promise of the gospel is described by Jenson as deification and he follows the thoughts of Basil the Great who said that the final result of the Spirit's work in us is 'endless joy in the presence of God, becoming like God, and ... becoming God' (Jenson 1999:311). Jenson says however that we should note the 'dialectics of Basil's vision: we will be simultaneously with God and so other than he, like God in sanctity and righteousness, and personally identified with God' (Jenson 1999:311). To emphasise that this understanding of salvation as deification is not only an Eastern peculiarity, Jenson also refers to Luther's interpretation in this regard (Jenson 1999:311). Jenson does however take care to specify the concept of deification and says firstly that 'because we become God, we do not cease to be creatures', secondly that 'we become what he is, humans so united with God as to "receive and bear God"', and thirdly that 'the redeemed do not become additional God-humans. Rather they become ... members of the totus Christus' (Jenson 1999:341). An image Jenson (1999) takes from Jonathan Edwards to describe this deification is that of music. He says that:

$[A] \mathrm{s}$ the harmony of the divine consciousness is finally musical, so the harmony of creation, sheerly as such, is musical. And since the very being of creation is this harmony, to be a creature is, in this respect, to be harmonized, to fit in an endlessly complicated web of mutually appropriate relations. (p. 41)

\section{Creation's dramatic teleology}

How will creation be part of this music, this conversation? Will creation also finally find its place in God? Jenson sees creation first of all as a stage where God's drama with his 
people takes place and says that, 'humanity is the reason for the rest of creation' and that 'the creation is a stage and players for our history with him' (Jenson 1999:115). Jenson qualifies this by saying, 'it does not follow, when galaxy clusters ... are once there, that they do not have their own meaning for the Creator' (Jenson 1999:115), but adds then that this reason is difficult for us to know. We have enough reason to believe, according to Jenson, that the 'universe is there to be the scene of our fellowship with God' (Jenson 1999:116), but creation is also part of the story of who God is with its own teleology. Jenson (1999) states:

Creatures who are neither human nor angelic ... the earth ... exist in that God wills there to be a stage for the story of the Son; and their coherence and regularities are partial orders established and unified in a teleology constituted by their bending to this eschatological plot. Thus arises the teleology that creation has also within itself. (p. 127)

The question remains: what will the end of the cosmos then be? What is the final 'place' (and value) of creation? Jenson says creation will finally also be included in the event who God is, because 'the triune God is too intimately involved with his creation for its final transformation to be founded in anything less than an event of his own life' (Jenson 1999:338), and therefore a cosmic transformation will take place after which 'the new creation will be an event in that "widest connection" of God's history with his creation' (Jenson 1999:349). The history of the universe will thus not proceed externally to the mutual human story, and cosmic history after the end will not be abstractable from human history. It would rather be that:

$[A]$ s the universe is the stage for the story of God with his people, so the universe after the End will be the stage for fulfilment of that story, for the eternal event of the interpretation of all lives by the life of Jesus. (Jenson 1999:350)

The teleology of the universe will thus be restored and the 'devil and his angels will have been finally expelled from the world ... there will be no teleological gaps or disruptions to give purchase to ateleological explanation' (Jenson 1999:351) of creation.

With creation and humans that will finally find their place in God, the relationship between humans and creation would be one where humans will enjoy creation in an aesthetic fashion. They will be able to do so because to be human is 'to participate in the triune conversation that is finally pure music and so pure delight, and because all creatures are the matter of this conversation' (Jenson 1999:130). When the redeemed are themselves a communal agent in the triune life, they will themselves think the 'movements of matter and energy, not as we may now trace a few of God's intentions after him but with God as he thinks and just so determines them' (Jenson 1999:350). In other words, when our time is fully congruent with God's, we 'may enjoy the material universe as he does, because we will not merely follow along in the triune music and delight but be improvisers and instigators within it' (Jenson 1999:351). We will play with star clusters and black holes with God in sheer enjoyment. This understanding of creation's true teleology and place in God brings a moral perspective to our current relation to creation. Jenson (1999) says that when we acknowledge our place in God, we may perceive a better way:

we may after all expand the second 'great commandment' to include not only our human neighbours but all our fellow creatures, if only we modulate to the aesthetic mode: 'You shall delight in each creature as in yourself.' (p. 130)

\section{Conclusion}

The relation between creation and salvation in Jenson's theology is as I said before, very strongly interwoven within his whole Trinitarian, narrative theology. The significance and importance of Jenson's theology lies in his unique Trinitarian 'accommodation' of creation and salvation. Creation is understood primarily as the stage for the drama between God and humans, but it is also part of this dramatic narrative with an eschatological hope. The creation is thus subjected to the curse of humanity's sin and the 'fall' had the implication that creation lost its true teleology. Creation is and must therefore be included in the salvation and Jenson therefore says in a typical Trinitarian way - with the emphasis on the future - that 'the creation is liberated to its End and Fulfilment by God the Spirit' (Jenson 1999:121). Therefore, the 'End, human and cosmic, will be the great triumph of the Spirit, that is, of freedom and love' (Jenson 1999:351). There is thus indeed a 'dramatic teleology of creation' and that has the implication that creation is not merely pointless or meaningless.

In Jenson's understanding, salvation is to become part of the being of God - it is to be reconciled to him so that we form part of the triune conversation or music. Salvation is thus understood as deification (as Jenson qualifies it) with the emphasis on our being harmonised with God, being part of the great 'fugue' he is. This salvation is also true for creation in that it will find its true harmony and teleology in the triune event of who God is. This perspective gives creation a much bigger value than normally assigned by science (or other theologies). The implication is therefore that our role with respect to creation must be one of much more responsibility. We have 'to tend our area of creation on behalf of the Creator to whom it continues to belong, taking our own subsistence from his generosity' (Jenson 1999:115). Our 'dominion' over creation means that we are stewards, we are gardeners of someone else's garden and it cannot therefore be abused. We are to delight in each creature and in creation as a whole, as we do in ourselves.

\section{Acknowledgements}

A word of appreciative thanks to Prof. Ernst Conradie (University of the Western Cape) who initiated this project and gave me some valuable guidance for writing the essay which preceded this article. This essay 'Robert Jenson (1930-) - A dramatic teleology of creation' was published in the book: Conradie, E.M. (ed.), 2012, Creation and salvation, vol. 2: A companion on recent theological movements, Münster, LIT Verlag. 


\section{Competing interests}

The author declares that he has no financial or personal relationship(s) which may have inappropriately influenced him in writing this article.

\section{References}

Braaten, C.E. \& Jenson, R.W. (eds.), 1984, Christian dogmatics, Fortress Press, Philadelphia. Braaten, C.E. \& Jenson, R.W. (eds.), 1996, The Catholicity of the reformation, Eerdmans, Grand Rapids.

Braaten, C.E. \& Jenson, R.W. (eds.), 2003a, In one body through the cross: The Princeton proposal for Christian unity, Eerdmans, Grand Rapids.

Braaten, C.E. \& Jenson, R.W. (eds.), 2003b, Jews and Christians: People of God, Eerdmans, Grand Rapids.

Braaten, C.E. \& Jenson, R.W. (eds.), 2004, The ecumenical future, Eerdmans, Grand Rapids.

Forde, G.O., 2000, 'Robert Jenson's Soteriology', in C.E. Gunton (ed.), Trinity, time, and church: A response to the theology of Robert W. Jenson, pp. 126-138, Eerdmans, church: A respons
Grand Rapids.

Gunton, C.E., 2000a, 'Creation and mediation in the theology of Robert W. Jenson: An encounter and a convergence', in C.E. Gunton (ed.), Trinity, Time, and Church: A response to the theology of Robert W. Jenson, pp. 80-93, Eerdmans, Grand Rapids.

Gunton, C.E. (ed.), 2000b, Trinity, time, and church: A response to the theology of Robert W. Jenson, Eerdmans, Grand Rapids.

Hart, D.B., 2005, 'The Lively God of Robert Jenson', First Things 156, 28-34.

Jenson, R.W., 1963, Alpha and Omega: A study in the theology of Karl Barth, Thomas Nelson, New York.
Jenson, R.W., 1969, God after God: The God of the past and the God of the future, seen in the work of Karl Barth, Bobs-Merrill, Indianapolis.

Jenson, R.W., 1973, Story and Promise: A brief theology of the gospel about Jesus, Fortress Press, Philadelphia.

Jenson, R.W., 1978, Visible words: The interpretation and practice of the Christian sacraments, Fortress Press, Philadelphia. PMCid:2018360

Jenson, R.W., 1982, Triune identity: God according to the gospel, Fortress Press, Philadelphia. PMCid:1916006

Jenson, R.W., 1992, Unbaptized God: The basic flaw in ecumenical theology, Fortress Press, Minneapolis.

Jenson, R.W., 1993, 'How the World Lost its Story', First Things 36, 19-24.

Jenson, R.W., 1995, 'Justification as a Triune Event', Modern Theology 11(4), 421-427. http://dx.doi.org/10.1111/j.1468-0025.1995.tb00074.x

Jenson, R.W., 1997, Systematic Theology, vol. 1: The Triune God, Oxford University Press, Oxford.

Jenson, R.W., 1999, Systematic Theology, vol. 2: The works of God, Oxford University Press, Oxford.

Mannermaa, T., 2000, 'Doctrine of Justification and Trinitarian Ontology', in C.E. Gunton (ed.), Trinity, time, and church: $A$ response to the theology of Robert $W$. Jenson, pp. 139-145, Eerdmans, Grand Rapids.

Mattes, M.C., 2000, 'An Analysis and Assessment of Robert Jenson's Systematic Theology', Lutheran Quarterly 14(4), 463-494.

Pannenberg, W., 2000, 'A Trinitarian Synthesis', First Things 103, 49-53.

Verhoef, A.H., 2008, 'How is Robert Jenson Telling the Story?', Scriptura: Internationa Journal of Bible, Religion and Theology in Southern Africa 98(2), 231-243.

Verhoef, A.H. 2011a, 'Timelessness, Trinity and temporality', Acta Academica 43(2), 82-112.

Verhoef, A.H., 2011b, 'Trinity, Time and Ecumenism in Robert Jenson's Theology' Dutch Reformed Theological Journal 52(1/2), 247-256. 